\title{
Assessment of Land Cover Dynamics and Drivers of Urban Expansion Using Geospatial and Logistic Regression Approach in Wa Municipality, Ghana
}

\author{
Mawuli Asempah *, Wahib Sahwan (D) and Brigitta Schütt
}

Citation: Asempah, M.; Sahwan, W.; Schütt, B. Assessment of Land Cover Dynamics and Drivers of Urban Expansion Using Geospatial and Logistic Regression Approach in Wa Municipality, Ghana. Land 2021, 10, 1251. https://doi.org/10.3390/ land10111251

Academic Editor: Kirsten de Beurs

Received: 21 October 2021

Accepted: 13 November 2021

Published: 16 November 2021

Publisher's Note: MDPI stays neutral with regard to jurisdictional claims in published maps and institutional affiliations.

Copyright: (C) 2021 by the authors Licensee MDPI, Basel, Switzerland. This article is an open access article distributed under the terms and conditions of the Creative Commons Attribution (CC BY) license (https:/ / creativecommons.org/licenses/by/ $4.0 /)$.
Department of Earth Sciences, Institute of Geographical Sciences, Freie Universität Berlin, Malteserstraße 74-100, 12449 Berlin, Germany; wahib.sahwan@fu-berlin.de (W.S.); brigitta.schuett@fu-berlin.de (B.S.)

* Correspondence: mawuli.asempah@fu-berlin.de; Tel.: +49-30-838-70239

\begin{abstract}
The current trends of land use dynamics have revealed a significant transformation of settlement spaces. In the Wa Municipality of Ghana, the changes in land use and land cover are inspired by a plethora of driving forces. In this study, we assessed the geo-physical drivers of settlement expansion under land use dynamics in the Wa Municipality of Ghana. The study employed geospatial and remote sensing tools to map and analyse the spatio-temporal dynamics of the landscape, using Landsat satellite imageries: thematic mapper (TM), enhanced thematic mapper (ETM) and operational land imager (OLI) from 1990 to 2020. The study employed a binomial logistic regression model to statistically assess the geo-physical drivers of settlement expansion. Random forest (RF)-supervised classification based on spatio-temporal analyses generated relatively higher classification accuracies, with overall accuracy ranging from $89.33 \%$ to $93.3 \%$. Urban expansion for the last three decades was prominent, as the period from 1990 to 2001 gained $11.44 \mathrm{~km}^{2}$ landmass of settlement, while there was $11.30 \mathrm{~km}^{2}$ gained from 2001 to 2010, and $29.44 \mathrm{~km}^{2}$ gained from 2010 to 2020. Out of the independent variables assessed, the distance to existing settlements, distance to river, and distance to primary, tertiary and unclassified roads were responsible for urban expansion.
\end{abstract}

Keywords: savannah vegetation; random forest classifier; regression analyses; receiver operating characteristics (ROC); urbanisation

\section{Introduction}

Urban land covers a relatively small proportion of the global terrestrial landscape but inhabits over half of the global population [1]. It is evident that despite its relatively small coverage, its expansion in the past decades has caused significant alteration to the environments globally [1,2]. Trends in urban land expansion and population over the past decades show that the increase in global population lags behind urban land expansion [3], although urban land expansion is associated with urbanisation, which is a product of population growth. Urbanisation coupled with urban land expansion exerts a profound impact on the environment, as it causes destruction of terrestrial ecosystems, leading to loss of biodiversity and the degradation of resources [4]. About $70 \%$ of the global anthropogenic greenhouse gas emissions emanate from urban areas and more than $80 \%$ of the global natural habitat loss is attributed to urban expansion [5].

Chen et al. [1] projected that global urban land will continue to expand with an increasing rate before the 2040s. They asserted that China and many other Asian countries might face significant pressure from urban population after the 2050s. It is supposed that global food security is endangered, as urbanisation and associated land expansion is expected to encroach on about $50-63 \%$ of the current crop land, leading to a consequential $1 \%$ to $4 \%$ decline in global crop production [6]. Similarly, Africa, with a predominantly rural landmass, is one of the fastest urbanizing regions in the world. The continent's population is expected to attain 1.34 billion in 2050 from 2010's 395 million estimate, 
constituting $21 \%$ of the global population projection [7]. Among the numerous drivers of changes in LULC changes, urbanisation presents a lasting and irreversible impact on the environment [8-10]. Increasing urbanisation and associated population exert pressure on natural resources and a high demand for the ecosystem services in effect, leading to critical environmental consequences, such as water crises, microclimatic alteration and natural resources degradation $[9,11]$. Temporal changes of landscapes are driven by urban development, as urban expansion coupled with population growth destruct the ecosystem, consequently impacting the provision of ecosystem services [12]. Lack of management plans to counteract the repercussions of the urban expansion imposes dire environmental consequences for ecological integrity and the provision of essential ecosystem services, such as water and raw materials. Ferreira et al. [13] established significant destruction in ecosystem as a result of urbanisation, among which the reduction of vegetation was prominent.

Exemplarily, we want to focus on Ghana, the second most populated state in Western Africa, which is in transition from an agrarian country to an industrial country. Ampim et al. [14] assessed land use and land cover (LULC) changes in Ghana from 1995 to 2019 to highlight significant changes and opportunities for sustainable development. They found the built-up area regionally to increase by 131.7\% over the entire 1995 to 2019 period. On the other hand, areas of bare land shrank by the average of $92.8 \%$, areas covered by grassland shrank by $51.1 \%$, and areas covered by diverse vegetation shrank by $41 \%$, respectively, over the same period. Ghana experienced significant population growth with associated LULC changes over the past six decades with a doubling of their population since 1990. In Ghana already in 2018, 56\% of the country's population dwelled in urban areas, which corresponds to the global trend, as, globally, $55 \%$ of people live in urban areas [15].

Both urban land expansion and population pose serious threats to the integrity of ecosystems and biodiversity [16], especially in drought-sensitive landscapes, such as those occurring in the Wa Municipality that is located within the semi-arid region of Ghana. Based on the above background, this study assessed the drivers of urban expansion in the Wa Municipality of Ghana in the past three decades to provide a basis for future landscape management and town planning to combat the municipality's transformational crisis and ensure ecosystem sustainability.

\section{Study Area}

The Wa Municipality is located in the Upper West region of Ghana (Lat. $10^{\circ} 14^{\prime} 46.32^{\prime \prime}$ $\mathrm{N} 09^{\circ} 42^{\prime} 5.04^{\prime \prime} \mathrm{N}$ and Lon. $02^{\circ} 33^{\prime} 14.04^{\prime \prime} \mathrm{W} 02^{\circ} 0^{\prime} 57.96^{\prime \prime} \mathrm{W}$ ). The area covers a total land of $579 \mathrm{~km}^{2}$ with a population of 102,214 inhabitants in 2010 [17] with a projected 132,646 inhabitants in 2020 [18]. It shares its administrative boundary with the Wa West District to the West and the Nadowli District to the East. The Wa Municipality (Figure 1) is located within the Guinea Savannah agrecological zone and is dominated by drought adaptation vegetation covers. The landscape is generally undulating with a height ranging from $248 \mathrm{~m}$ to $368 \mathrm{~m}$ above sea level (Figure 2). Low-lying areas constitute two main drainage system in the capital and also retain water for a long period during the long rainy season [17]. Economic trees, such as baobab (Adansonia digitata), shea tree (Butylosternum paradoxum), teak (Tectona grandis) and dawa dawa (Parkia biglolosa) spread across the area where inhabitants leverage their potentials for livelihood diversification and development $[19,20]$. Seasonal bushfires coupled with climate variability and increasing built-up areas impose a threat to the benefits derived from the economic trees, thus affecting livelihood [21]. The climate of the district is characterised by two seasons, at a time controlled by the southwest monsoon winds and the northeast trade winds. The southwest monsoon wind is associated with the rainy season that lasts from May to September.

The Wa Municipality is located within the semi-arid savannah high plains with characteristic mixed woody vegetation and an open savannah ecosystem with predominating widely spaced trees. Agricultural production and activities related to the agricultural value 
chain are the major economic activities in the area, employing over $29.3 \%$ of the labour force, with a significant proportion (18.5\%) engaged in crafts and related trades [17]. The major staple foods cultivated in the district include millet (Panicum miliaceum), cowpea (Vigna unguiculata), maize (Zea mays), yam (Dioscorea spp.), sorghum (Sorghum bicolor) and groundnut (Arachis hypogaea) [17]. Despite the dominant contribution of the agricultural sector to employment and livelihoods in the region, the services sector, in most recent times, has gained importance, employing up to about $25.7 \%$ of the labour force in 2010 [17,22].

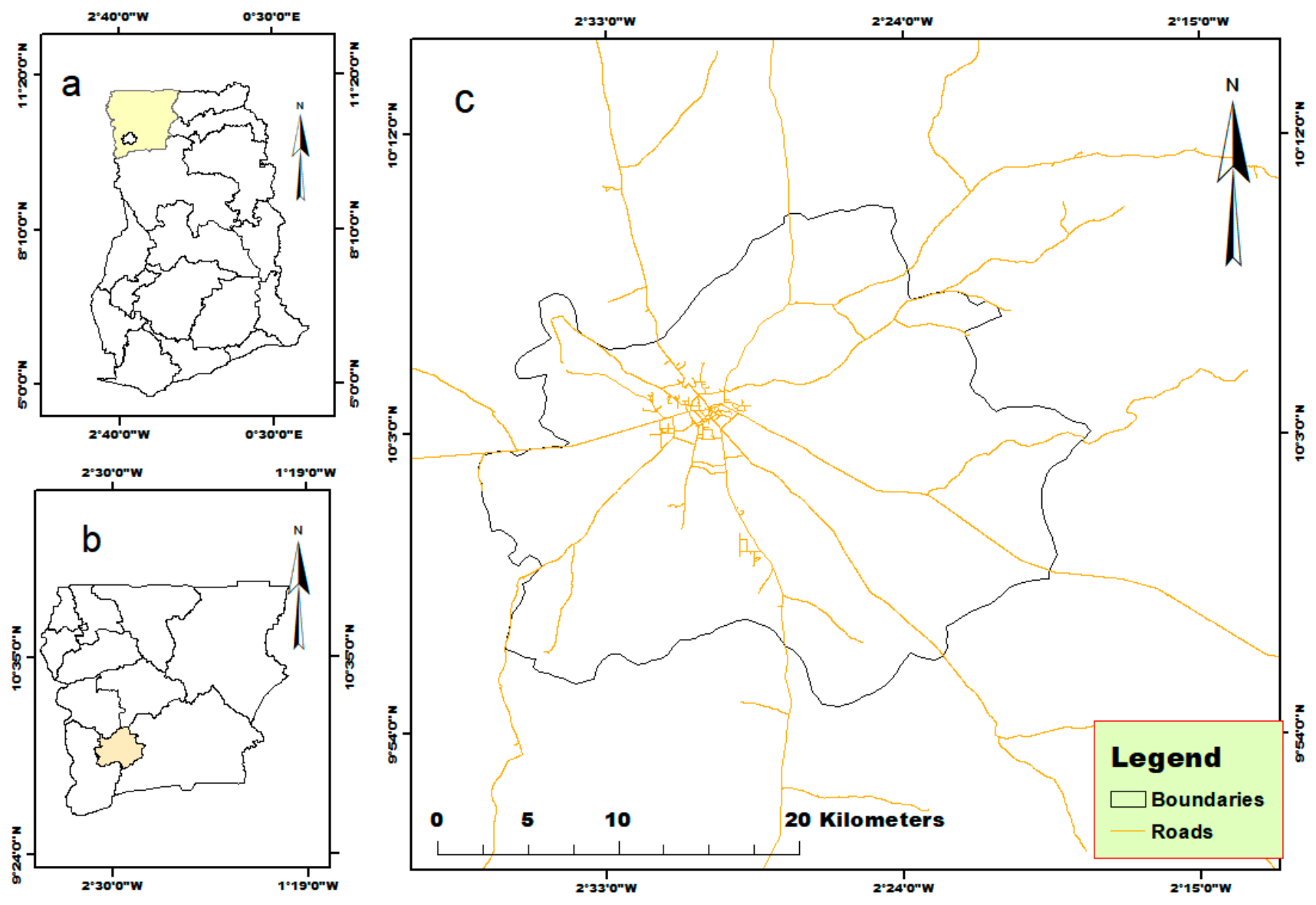

Figure 1. Map of the Wa Municipality located at the Upper West Region of Ghana. (a) Map of Ghana showing its sixteen regions separated by administrative boundaries; the Upper West region is marked by shading. (b) Upper West region showing its eleven districts separated by administrative boundaries; Wa Municipality is marked by shading. (c) The study area location (Wa Municipality) with road network. 


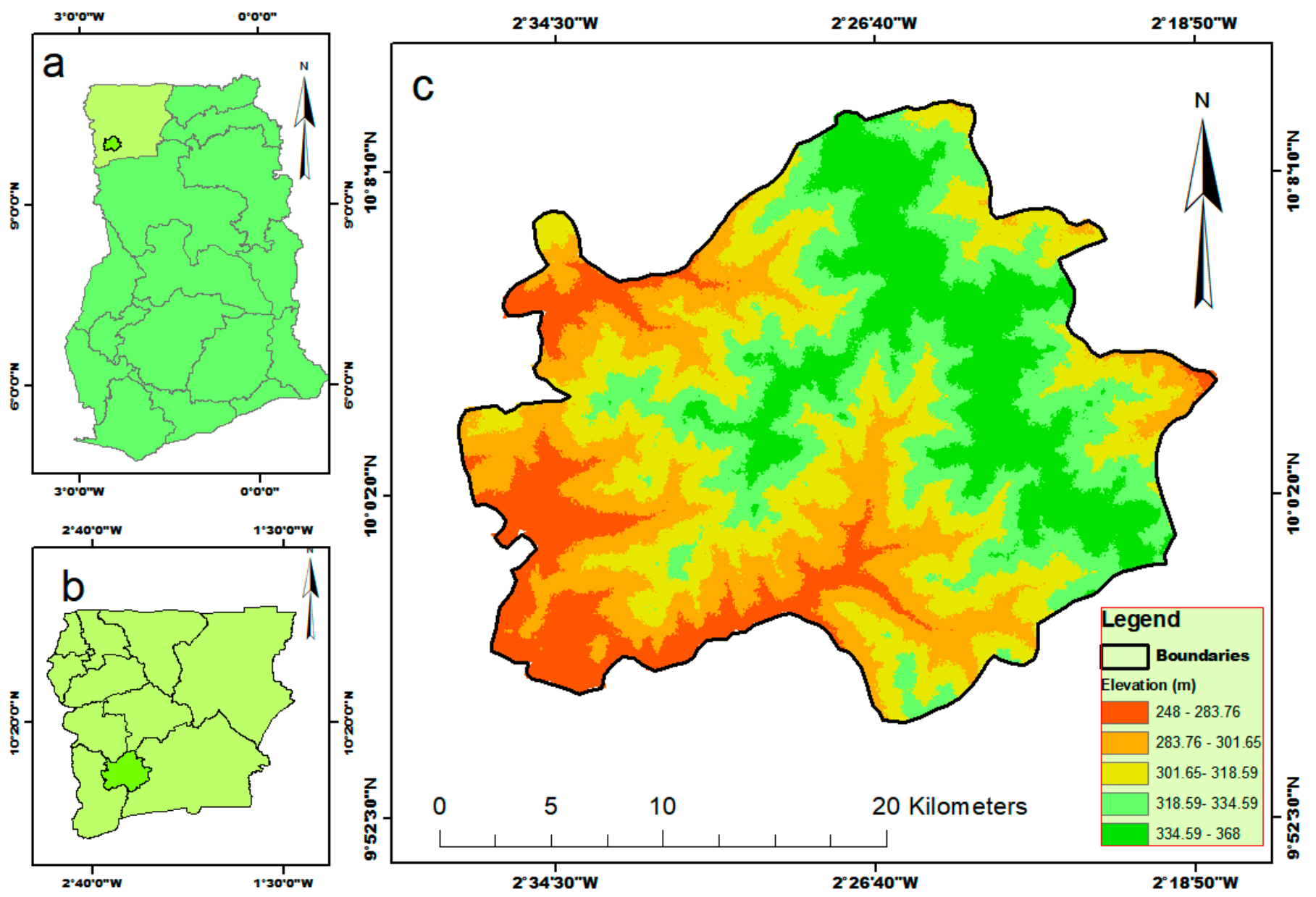

Figure 2. Land elevation map of Wa Municipality located at the Upper West Region of Ghana. (a) Map of Ghana showing its sixteen regions separated by administrative boundaries; the Upper West region is marked by shading. (b) Upper West region showing its eleven districts separated by administrative boundaries; Wa Municipality is marked by shading. (c) Digital elevation model (DEM) of the Wa Municipality; the black line marks the administrative boundary of Wa Municipality. (Data source: Shuttle Radar Topography Mission (SRTM) DEM from United States Geological Survey's Earth Explorer website, on https:/ / earthexplorer.usgs.gov/, accessed on 14 September 2020.)

\section{Data and Methods}

\subsection{Data Acquisition and Processing}

This study explores the landscape dynamics of Wa Municipality, Ghana, of the past three decades (from 1990 to 2020), focusing on the time slices 1990, 2001, 2010 and 2020. The study acquired Landsat thematic mapper (TM), enhance thematic mapper (ETM) and operational land imager (OLI) images of $30 \mathrm{~m} \times 30 \mathrm{~m}$ spatial resolution from the United States Geological Survey's (USGS) Earth Explorer website (https: / / earthexplorer. usgs.gov/, accessed on 15 March 2021). To achieve the spatio-temporal analysis, Landsat TM5 data were acquired for the year 1990 and ETM data for the years 2001 and 2010, while OLI data were acquired for the year 2020 (Table 1 and Table S1). All imageries selected are completely free from cloud cover and were acquired for the same season (October to November) to minimise the effects of seasonal variation in the vegetation pattern and distribution. 
Table 1. Characteristics of data used for image classification and their date of acquisition.

\begin{tabular}{cccccc}
\hline Satellite Name & Sensor & Number of Bands & Path/Rows & Spatial Resolution & Date of Acquisition \\
\hline Landsat 5 & TM & 7 & $195 / 053$ & $30 \mathrm{~m}$ & 12 October 1990 \\
Landsat 7 & ETM & 9 & $195 / 053$ & $30 \mathrm{~m}$ & 3 November 2001 \\
Landsat 7 & ETM & 9 & $195 / 053$ & $30 \mathrm{~m}$ & 12 November 2010 \\
Landsat 8 & OLI & 11 & $195 / 053$ & $30 \mathrm{~m}$ & 15 November 2020 \\
\hline
\end{tabular}

The selected satellite images were of good quality, except the ETM imageries, which were characterised with defects due to the failed scan line corrector (SLC). The failed SLC resulted in the missing of about $22 \%$ of the normal scene area of the ETM data [23]. This anomaly was corrected, using Landsat Toolbox integrated in ArcGIS 10.5 software to reduce the consequential effects on the image classification accuracy. The imageries were corrected for radiometric distortion to present the inhibition of the spectral characteristics of the land features [24]. The semi-automatic classification plugin (SCP) of QGIS 3.4 software was used for dark object subtraction, which, in effect, enabled the correction of the atmospheric distortion and conversion of digital numbers (DNs) to spectral reflectance $[25,26]$. Subsequently, the Landsat imageries for all the considered years were subjected to further pre-processing, including stacking and clipping with a projected study area vector map to enable high precision classification of the image and its associated computations. The spectral bands stacked for all the sensors include blue, green, red, NIR and SWIR; the thermal bands which could impact the quality of the images and effect the classification accuracy were excluded $[27,28]$.

\subsection{Use of Spectral Indices for Extracting Landscape Features}

Spectral indices combine spectral reflectance from wavelengths used in highlighting and enhancing the interpretability of landscape features (Table 2; [29]) and, thus, are widely adopted in modelling and monitoring land surface phenomena. The spectral indices used in the LULC classification to extract spectral information for the categorisation of urban areas, vegetation covered areas and water features include the normalised difference vegetation index (NDVI), normal difference built-up index (NDBI) [30], soil-adjusted vegetation index (SAVI), normalised burn ratio 2 (NBR2) and modified normalised difference water index (MNDW) [31,32]. These were additionally applied for LULC classification to cope with the regional landscape's high intra-heterogeneity. The identification and classification of built-up areas was supported by NDBI computation (Table 2, Equation (1)) that utilises shortwave-infrared (SWIR) and near-infrared (NIR) multispectral bands [33]. These extract built-up areas and barren land and secludes areas covered by water and vegetation. NDBI is applicable with a multispectral sensor with a SWIR band between $1.55 \mu \mathrm{m}$ and $1.75 \mu \mathrm{m}$ and $\mathrm{a}$ NIR band between $0.76 \mu \mathrm{m}$ and $0.9 \mu \mathrm{m}$.

Table 2. Summary of spectral indices used for LULC classification.

\begin{tabular}{|c|c|c|c|}
\hline ID & Index & Formula & Equation \\
\hline 1 & NDBI & $\frac{\text { SWIR-NIR }}{\text { SWIR+NIR }}$ & (1) \\
\hline 2 & NDVI & $\begin{array}{l}\text { NIR-Red } \\
\text { NIR+Red }\end{array}$ & (2) \\
\hline 3 & SAVI & $\frac{\mathrm{NIR}-\mathrm{Red}}{\mathrm{NIR}+\operatorname{Red}+\mathrm{L}} \times(1+\mathrm{L})$ & (3) \\
\hline 4 & NBR2 & $\frac{\text { SWIR1- SWIR2 }}{\text { SWIR1+ SWIR2 }}$ & (4) \\
\hline 5 & MNDWI & $\begin{array}{l}\text { Green-SWIR } \\
\text { Green+SWIR }\end{array}$ & (5) \\
\hline
\end{tabular}

Through a normalised computation procedure and mathematical expression, NDVI utilises red and NIR Landsat bands to significantly enhanced green vegetation (Table 2, Equation (2)) [30,34]. Since its introduction by Rouse et al. [30], NDVI became the most widely used vegetation index in interpreting vegetation characteristics of complex land- 
scapes [34]. Due to the complex landscape of the Wa Municipality, the NDVI was corroborated with SAVI and NBR2 (Table 2, Equations (3) and (4)). The SAVI accounted for the deficiencies in NDVI in terms of the stability of vegetation and soil characteristics as a result of the loss of spectral differential red and infrared by vegetation canopy. SAVI incorporates a soil brightness correction factor $(\mathrm{L})$ in the range of 0 (for dense vegetation cover) to 1 (for low vegetation cover). The NBR2, on the other hand, assists in identifying areas recovering from bushfire, which otherwise would be interpreted as built-up areas.

The MNDWI enhances the extraction of open water features from landscapes (Table 2, Equation (5)). It is an improved form of the normalised difference water index (NDWI) by McFeeters [35] that utilises green and NIR bands in extracting water features. McFeeters' NDWI computation shows higher spectral reflectance in green light than NIR light for both built-up areas and areas covered by water, in effect, producing positive values for both. The computation of MNDWI substitutes SWIR for NIR as proposed by $\mathrm{Xu}$ [32]. This procedure yields a better result in extracting water features from the landscape because of water's ability to absorb SWIR better than NIR, leading to an increased positive value for MNDWI [32].

\subsection{LULC Classification and Change Detection}

Pixel-based supervised LULC classification [36] was carried out on each pre-processed Landsat images for the years 1990, 2001, 2010 and 2020. Six LULC classes (closed savannah vegetation, open savannah vegetation, other, settlement, vegetated wetland and water), adapted from Ghana's LULC classification scheme for visual characterisation of remote sensing data [37], were identified through ground truthing for the spatio-temporal classification (Table 3). A non-parametric-based RF classifier was used to generate the thematic maps through a supervised classification approach for each respective year from their stacked spectral bands and the relevant spectral indices. The integration of spectral indices enhances the identification of landscape features for built up, greenness, brightness and wetness. Built-up areas within the Wa Municipality were classified into settlement areas as identified in diverse spectral features of the Landsat satellite images corroborated by the NDBI spectral index. The characterisation of vegetation cover was supported by enhancement with the SAVI and NDVI spectral indices; integration of the NBR2 index helped to identify vegetation covers that regenerated after bushfire. The vegetation cover was categorised into closed savannah, open savannah and vegetated wetland. The distinction of closed and open savannah vegetation was influenced by the dominance of woody biomass within a hectare space. A threshold of less than 150 trees per hectare is categorised into open savannah, and a hectare of land with more than 150 trees, which is characteristic of forests and reserves, is considered closed savannah. The vegetated wetland class predominantly corresponds to water channels previously inundated with water that are overgrown with dense grasses and shrubs. This class has the highest spectral values in the vegetation indices. The application of MNDWI to the Landsat images supported the identification and classification of water bodies. Ground truthing of the six LULC classes was conducted in a field campaign in 2020 (Table 3).

On-site random points were collected for each LULC class, using Garmin 60Cx GPS, serving as the reference for the classification and validation of the stacked Landsat image for 2020 with an $80 \%$ and $20 \%$ split for training and test data, respectively. Training samples were created by digitising polygons and selecting sample pixels from each of the pre-processed Landsat images for the established LULC classes. Each of the ground truth LULC classes was verified by visual interpretation of the Landsat satellite images (Table 1) supported by topographic maps (scale 1:50,000 published in 1999 by the Survey of Ghana) and Google Earth and Bing high-resolution imagery (acquired via Web Map Service, WMS) [38,39]. An accuracy matrix was created for the respective years $(1990,2001$, 2010 and 2020) to assess the performance of the random forest classification algorithm by assessing the error matrices and overall accuracy of agreement. Frequency statistics were 
conducted to establish the quantities of spatial changes in each class for the time periods of

1990-2001, 2000-2010, 2010-2020, and the overall period from 1990 to 2020.

Table 3. Description of LULC classes of the study.

\begin{tabular}{lll}
\hline ID & LULC Class & Description \\
\hline 1 & Closed savannah & $\begin{array}{l}\text { This is characterised with dense vegetation, predominantly woody cover, such as } \\
\text { natural forest, and reserved and protected areas with tree population density of more } \\
\text { than } 150 \text { trees per hectare. }\end{array}$ \\
\hline 2 & Open savannah & $\begin{array}{l}\text { These are areas with less dense vegetation cover with tree population density of fewer } \\
\text { than } 150 \text { trees per hectare. The vegetation cover is predominantly sacred groves and } \\
\text { thick shrub and grasses. }\end{array}$ \\
\hline 3 & Other & $\begin{array}{l}\text { Areas without vegetation cover, bare lands, rocky surfaces, sand, gravel andunregulated } \\
\text { open mining pits. }\end{array}$ \\
\hline 5 & Settlement & Built-up areas, towns, and emerging residential areas with low to medium density. \\
\hline 6 & Vegetated wetland & $\begin{array}{l}\text { Dried-up rivers and stream channels and areas previously inundated with water that } \\
\text { are overgrown with grasses and shrubs. }\end{array}$ \\
\hline
\end{tabular}

\subsection{Locational Factors}

Data on locational characters were obtained from broad categories of factors, including topographic factors and location factors. The topographic factors were derived from a shuttle radar topography mission (SRTM) digital elevation model of $30 \mathrm{~m}$ ground resolution, acquired from the United States Geological Survey database (https: / / earthexplorer.usgs. gov/, accessed on 14 September 2020). Topographic factors were calculated as derivatives from this digital elevation model (DEM), including slope, aspect, and topographic wetness index (TWI). The location factors were processed with the Euclidean distance tool in ArGIS 10.5 version to obtain the raster layers that served as location independent variables (distance from existing settlement, distance to primary roads, distance to tertiary roads, distance to stream, and distance to rivers). The existing settlements were extracted from the LULC maps for 1990, 2001 and 2010; these data were used to establish the proximity relationship for the changes that occurred from 1990 to 2001, 2001 to 2010 and 2010 to 2020. Additional locations, such as open water, streams, primary roads, and tertiary roads, were acquired from OpenStreetMap and Geofabrik.

\subsection{Binomial Logistic Regression \\ 3.5.1. Selection of Variables (Factors Contributing to Urban Expansion)}

A binomial logistic regression model was used to explore the explanatory drivers of settlement expansion over the study period. The independent variables were selected from previous studies that assessed the drivers of urban expansion in the context similar to our study. According to Xu et al. [40] and Dubovyk et al. [41], there are diverse driving factors of settlement expansion. In the modelling of urban expansion, the geographical location and its prevailing conditions are important in selecting the independent variable. In the context of emerging compacted cities, such as the Wa Municipality, topographical and location factors are relevant and could influence urban expansion. Consistent with previous locational studies in developing contexts that have similar attributes to the Wa Municipality [41,42], topographical and location factors were selected as potential independent variables from various sources (Section 3.4) with the highest likelihood of influencing urban expansion in the study municipality.

In a study of linkage between drivers and axis of urban expansion in Zimbabwe, Marondedze and Schütt [42] identified slope and distance proximity characters as statistical significant predictors of urban growth. Similarly, $\mathrm{Li}$ [43] found slope and location factors, such as distance to major roads, distance to highway and distance to city centre, as drivers of urban expansion. This agrees with other studies which established the same characters 
as determinants of urban expansion $[41,44,45]$. The proximity to water networks was studied extensively in both developed and developing context and was proven to be an important driver of urban expansion [44,46]. Based on the established relevance of the topography and location characters in urban expansion, our study explores slope, aspect, TWI, distance to settlements, distance to primary roads, distance to tertiary roads, distance to unclassified road, distance to river, and distance to stream (Figures S2 and S3) as the independent variables for modelling urban expansion in the Wa Municipality.

\subsubsection{Model Development}

The raster layers for areas expanded from the time steps (1990-2001, 2001-2010, 2010-2020 and the entire period of 1990-2020) serve as dependent variables to explore the drivers of change (Figure S1). The cells from the raster layers were transformed to dichotomous variables, where any area newly transformed to settlement land use is considered settlement expansion and denoted with " 1 ", while already existing urban areas and other areas occupied by landscape features that did not transform into settlement areas in the subsequent time slice are considered non-expansion areas and denoted with a dichotomy value of " 0 ".

A total of 6000 stratified random sample points were created from all classification maps to extract values for the regression analysis. We set up the binomial logistic model after all the dependent and independent variables were processed. The model was taken to be statistically significant at $p<0.05$. Given this, all independent variables that were specified and fitted into the model and produced $p$-values less than 0.05 are taken as statistically significant predictors of urban expansion in the study municipality. The model performance was evaluated to assess the discriminatory of the result using the receiver operating characteristic curve (ROC) and its area under the curve (AUC). The ROC and AUC rely on accuracy matrices, which is a measure of the proportion of correctly classified positive sampling points (true positive rate: TPR), and the proposition of incorrectly classified positive (false positive rate: FPR) [47].

\section{Results}

\subsection{The Extent of Land Use and Land Cover Change}

The spatio-temporal analysis reveals varying extents of change of the LULC features for the three-decade periods that span from 1990 to 2020 (Figures 3 and 4). In general, the Wa Municipality is characterised by savannah vegetation, with open savannah covering the largest extent of the area. In 1990, the total extent of open savannah was $407.22 \mathrm{~km}^{2}(70.30 \%$ of the total spatial extent of the Wa Municipality). The LULC analysis revealed dynamics in the open savannah coverage in subsequent time steps, as there were some gains in the open savannah coverage in the year 2001 with a total spatial extent of $417.06 \mathrm{~km}^{2}$ (72.0\%). Overall, the open savannah reduced to $392.25 \mathrm{~km}^{2}$ (67.72\%) in 2020. As vegetation cover reduced within the three-decade time frame, closed savannah vegetation covered $128.69 \mathrm{~km}^{2}(22.22 \%)$ of the total area in 1990 and reduced to $91.34 \mathrm{~km}^{2}(15.77 \%)$ in the year 2020 (Table 4).

The reduction of areas covered by closed savannah vegetation more or less stagnated between the year $2001\left(119.32 \mathrm{~km}^{2} ; 20.60 \%\right)$ and $2010\left(107.21 \mathrm{~km}^{2} ; 18.51 \%\right)$. Similarly, areas covered by vegetated wetland decreased from $13.3 \mathrm{~km}^{2}(2.30 \%)$ in 1990 to $12.73 \mathrm{~km}^{2}(2.16 \%)$ in 2020; for the year 2010, the highest coverage of $14.59 \mathrm{~km}^{2}(2.52 \%)$ was observed. Beyond, the analysis showed continued increase in settlement expansion with an expansion of eight times the area covered by settlements between $1990\left(7.44 \mathrm{~km}^{2}, 1.28 \%\right)$ and $2020\left(59.86 \mathrm{~km}^{2}, 10.33 \%\right)$. 

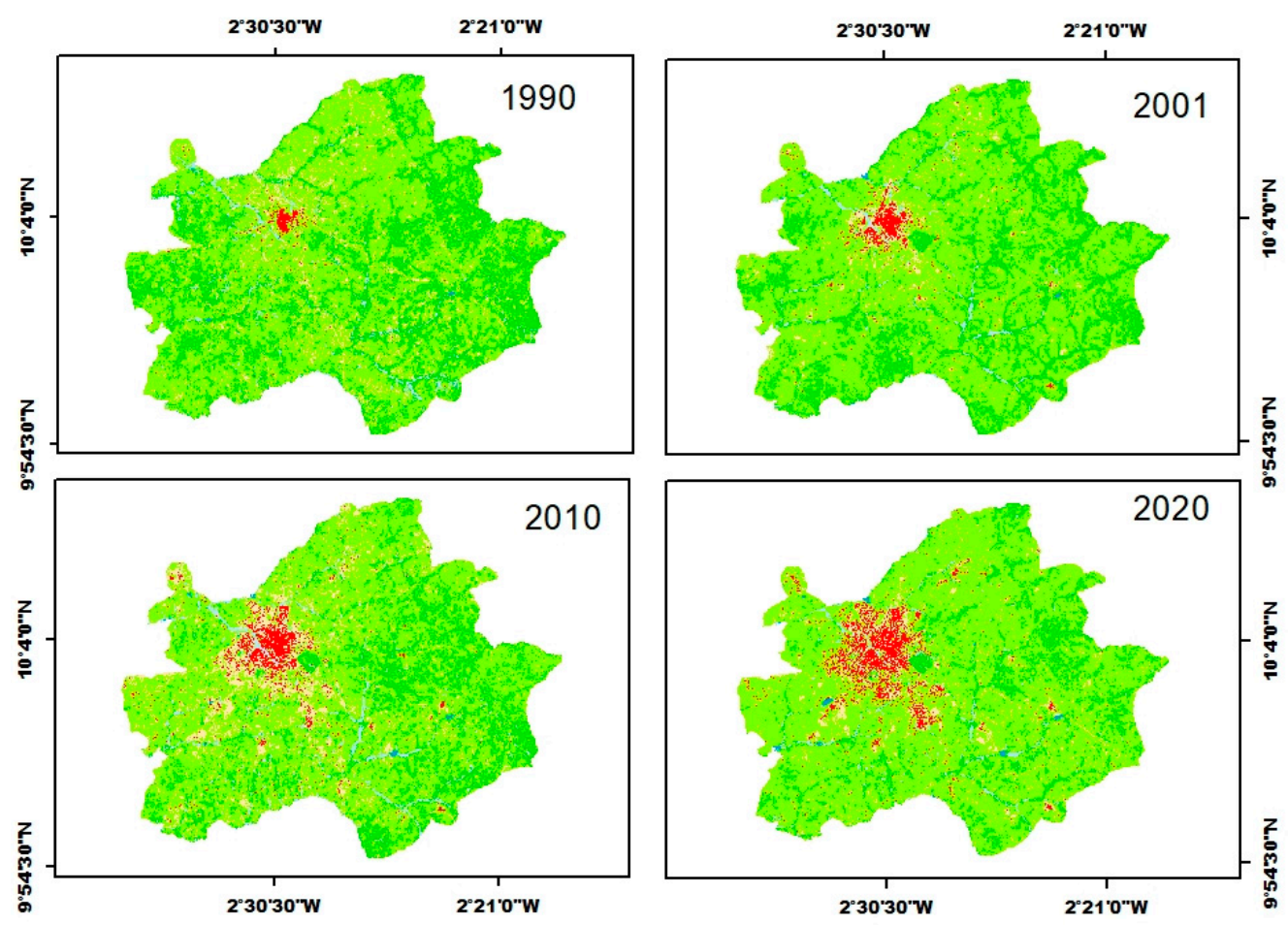

\section{Legend}

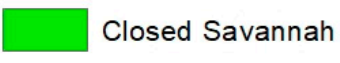

Open Savannah

Other

Settlement

Vegetated Wetland

Water

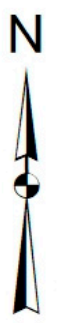

\section{$\begin{array}{llll}0 & 5 & 10 & 20 \text { Kilometers }\end{array}$}

Figure 3. Land use and land cover map for Wa Municipality for the year 1990, 2001, 2010 and 2020.

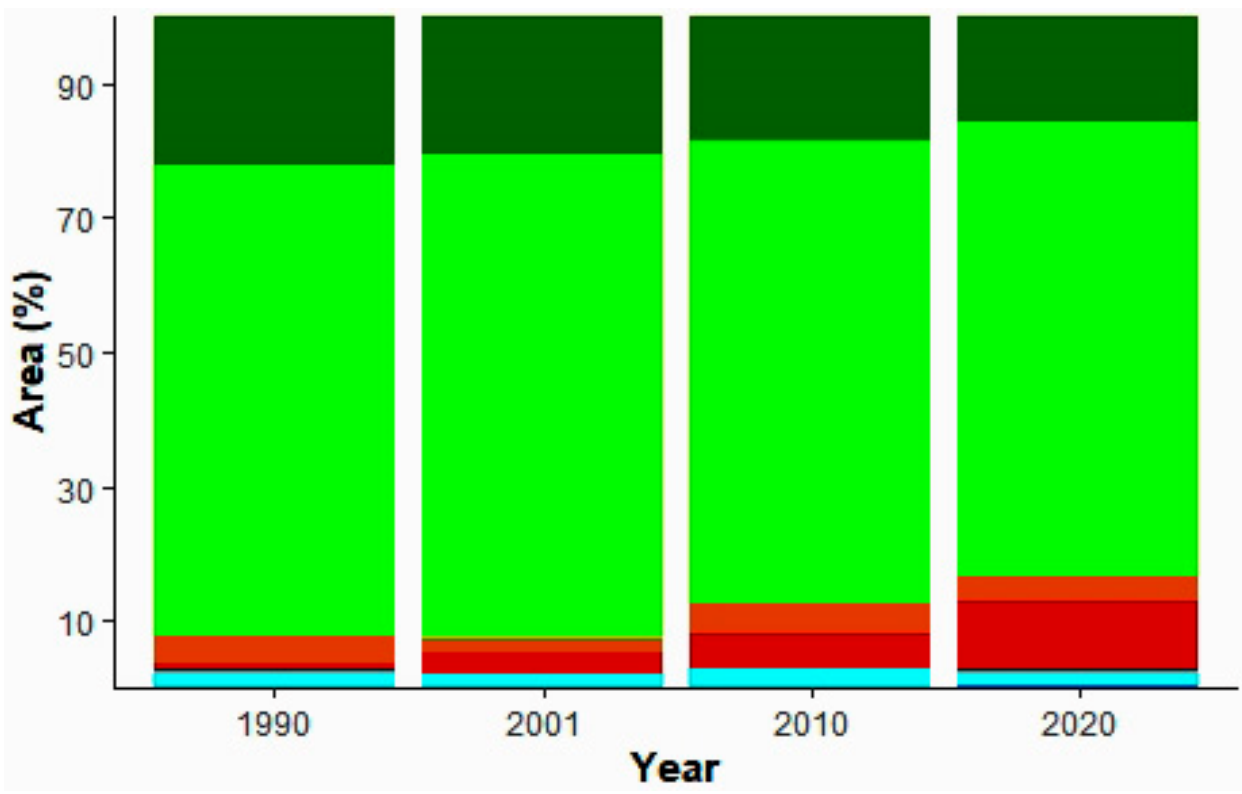

\section{Class}

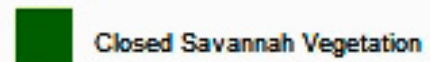

Open Savannah Vegetation

Other

Settlement

Vegetated Wetland

Water

Figure 4. The proportion of LULC change in Wa Municipality for the respective time slices. 
Table 4. Spatial changes of land area for the land use and land cover classes in Wa Municipality for the 1990, 20012010 and 2020 time series.

\begin{tabular}{lllllllll}
\hline LULC Class & $\begin{array}{l}\mathbf{1 9 9 0} \\
\mathbf{k m}^{\mathbf{2}}\end{array}$ & $\mathbf{9}$ & $\begin{array}{l}\mathbf{2 0 0 1} \\
\mathbf{k m}^{\mathbf{2}}\end{array}$ & $\mathbf{\%}$ & $\begin{array}{l}\mathbf{2 0 1 0} \\
\mathbf{k m}^{\mathbf{2}}\end{array}$ & $\mathbf{\%}$ & $\begin{array}{l}\mathbf{2 0 2 0} \\
\mathbf{k m}^{\mathbf{2}}\end{array}$ & \begin{tabular}{l}
$\mathbf{\%}$ \\
\hline Closed savannah
\end{tabular} \\
Open savannah & 128.69 & 22.22 & 119.32 & 20.60 & 107.21 & 18.51 & 91.34 & 15.77 \\
Other & 407.22 & 70.30 & 417.06 & 72.00 & 400.61 & 69.16 & 392.25 & 67.72 \\
Settlement & 22.18 & 3.83 & 12.98 & 2.24 & 25.62 & 4.42 & 22.11 & 3.82 \\
Vegetated wetland & 7.44 & 1.28 & 19.12 & 3.30 & 30.42 & 5.25 & 59.86 & 10.33 \\
Water & 13.30 & 2.30 & 10.33 & 1.78 & 14.59 & 2.52 & 12.73 & 2.16 \\
\hline
\end{tabular}

The settlement expansion predominantly took place into the southern direction. Most of these spatial expansions between 1990 and 2020 predominantly occurred within areas previously characterised by open savannah vegetation and areas without vegetation. The class "other" primarily corresponds to areas other than vegetation and water and shows a relatively stable spatial extent over the observation period; the total spatial extent of $22.18 \mathrm{~km}^{2}(3.83 \%)$ in the base year 1990 only reduced by $0.01 \%$, as the total area covered in 2020 was $22.11 \mathrm{~km}^{2}(3.82 \%)$. Areas covered by water during the entire observation period are relatively low but increased from $0.39 \mathrm{~km}^{2}(0.07 \%)$ in 1990 to $0.93 \mathrm{~km}^{2}(0.2 \%)$ in 2020 .

\subsection{Accuracy Assessment for Land Use and Land over Classification}

Relatively high overall accuracy (OA) was recorded for each time slice, ranging from $89.33 \%$ (2001) to $93.3 \%$ (2020) (Table 5). The user accuracy (UA) reflects the reliability of the classification, while producer accuracy (PA) reveals how well the reference pixel of land cover types are classified. The class water had the highest producer's accuracy for all the time slices (Table 5). Generally, a relatively high degree of classification accuracy runs through all the time slices for all LULC classes.

Table 5. User's accuracy (UA), producer's accuracy (PA) and overall accuracy (OA) for land use land cover classification accuracy assessment for the time slices.

\begin{tabular}{|c|c|c|c|c|c|c|c|c|c|c|c|c|c|}
\hline \multirow{2}{*}{ Class } & \multicolumn{2}{|c|}{ Closed Savannah } & \multicolumn{2}{|c|}{ Open Savannah } & \multicolumn{2}{|c|}{ Other } & \multicolumn{2}{|c|}{ Settlement } & \multicolumn{2}{|c|}{ Vegetated Wetland } & \multicolumn{2}{|c|}{ Water } & \multirow{2}{*}{ OA } \\
\hline & UA & PA & UA & PA & UA & PA & UA & PA & UA & PA & UA & PA & \\
\hline 1990 & 92 & 97.87 & 94 & 82.46 & 80 & 93.02 & 96 & 92.31 & 98 & 94.23 & 96 & 97.96 & 92.67 \\
\hline 2001 & 88 & 93.62 & 96 & 78.69 & 82 & 78.85 & 84 & 93.33 & 92 & 97.87 & 94 & 97.92 & 89.33 \\
\hline 2010 & 88 & 93.6 & 96 & 75 & 88 & 93.6 & 92 & 93.9 & 82 & 89.1 & 92 & 97.9 & 89.7 \\
\hline 2020 & 92 & 92 & 94 & 87.0 & 94 & 95.9 & 90 & 93.8 & 94 & 94 & 96 & 98 & 93.3 \\
\hline
\end{tabular}

\subsection{Binomial Logistic Regression and Model Validation}

A receiver operating characteristic (ROC) curve (Figure 5) is a graphical plot of the true positive rate (sensitivity) against the false positive rate (1-specificity) and illustrates the diagnostic ability of a binary classifier [48]. This produces an area under the curve (AUC) that measures the discriminating power of a model. The area under the curve (AUC) is an effective and combined measure of sensitivity and specificity for assessing the inherent validity of a test $[47,48]$. The larger the area under the ROC curve, the stronger the predictive power of the model [48]. As a broader acceptable standard, a model with maximum AUC (1.0) has a perfect descriptive power, with 0.9 being considered excellent. A perfect descriptive power of the model is an indication of having all the true positive rates (sensitivity) and true negative rates (specificity) as one and both errors (false positive and false negative) as zero. In a complete random relationship, the model produces an AUC of 0.5 with a diagonal line from the left bottom to the upper right corner. For a model to be considered efficient, it must possess at least 0.6 power. A power of 0.7 is considered good, while 0.8 is regarded as very good [47]. 
(a)

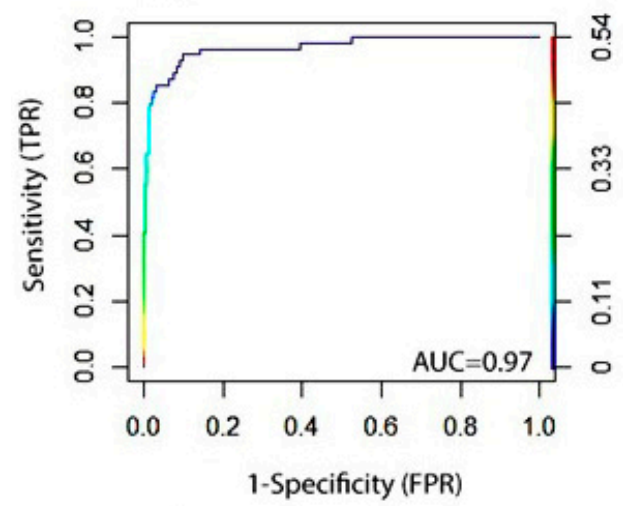

(c)

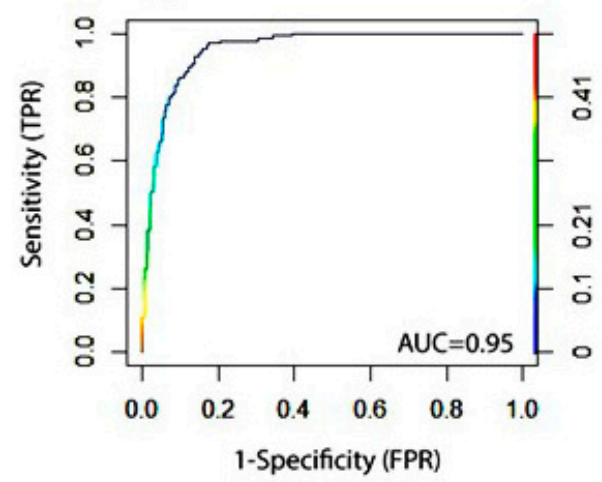

(b)

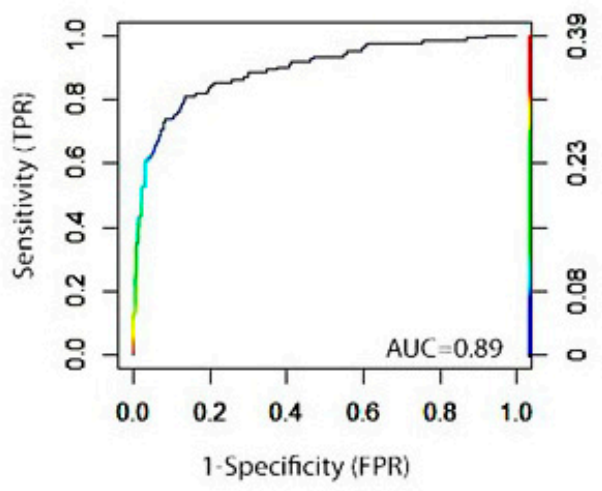

(d)

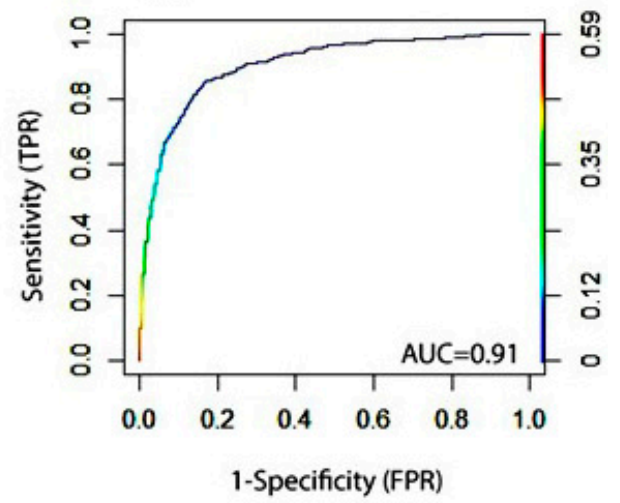

Figure 5. Receiver operating characteristic (ROC) curves depicting validity and performance of binomial logistic regression analyses results for urban expansion in Wa Municipality for the following years: (a) 1990, (b) 2001, (c) 2010 and (d) 2020. (FPR: false positive rates; TPR: true positive rates; AUC: area under the curve).

Through the binomial logistic regression modelling, it was evident that topographic factors (slope, aspect, topographic wetness index) were not statistically significant to urban expansion. In contrast, the location factors were, for all the time steps, statistically significant. The distance to the existing settlement was significant at $p<0.001$ for all time steps. Similarly, the distances to primary roads, tertiary roads, and unclassified roads were significant at $p<0.001$ for all time steps, except for the time step of 2001 to 2010, where the distance to tertiary roads and distance to unclassified roads were of less powerful statistical significance $(p<0.05)$. The distance to rivers was also significant at $p<0.01$ for time step 1990-2001 and $p<0.001$ for time step 2001-2010. The receiving operating characteristic (ROC) curve was used to validate the model performance. The discriminatory power of the model was very high for all time steps (Figure 5). The ROC for 1990 produced the best performing descriptive and predictive model, with an AUC of 0.97. The least was observed in the model for 2001-2010 (AUC = 0.89). Summarizing, all the models for the four time steps selected are valid and satisfactory for describing and predicting the urban expansions in the Wa Municipality.

\section{Discussion}

The transformation of the natural vegetation and the functioning of the terrestrial ecosystems are influenced by the ongoing urban sprawl and its associated environmental changes. The Wa Municipality, and the Upper West Region of Ghana as a whole, has seen significant changes regarding demography and ecological landscapes over the past decades and most likely will be impacted in the years to come [49]. The spatio-temporal LULC classification of the Wa Municipality reveals the dynamics of urban expansion and associated changes in the landscape between 1990 and 2020. The classification was 
accomplished with high overall accuracies. The relatively high accuracy was achieved by the non-parametric RF machine learning classifier, which was identified to produce better LULC classification accuracy than non-parametric and traditional parametric classifiers [50]. In a review of LULC classification using the machine learning classifier for satellite imageries, Talukdar et al. [51] concluded that in a high dynamic landscape with intra-heterogeneity, as is also typical for the Wa Municipality, the RF classifier provides better classification accuracy than other machine learning classifiers when modelling LULC changes, especially when imageries have the same sensor characteristics, such as spatial and temporal resolution $[52,53]$.

The random forest $(\mathrm{RF})$ classification algorithm provides a great opportunity to generate higher classification accuracy outputs than parametric classifiers [50]. The success of high classification accuracies was achieved by the corroboration of the RF classifier with the application of spectral indices. The spectral indices in the LULC assessment of this study in turn enhanced the delineation of the landscape features, making the clear distinction between the different LULC classes more prominent and, thus, increased the accurate selection of training samples and, subsequently, the LULC classification accuracy. The high accuracies generated by incorporating spectral indices agrees with Hegazy et al. [54], who established increased separability between LULC classes in the quest to analyse land use and land cover changes, using spectral indices. Owing to the vegetation cover complexity of the Wa Municipality, intra-vegetation separability was enhanced by the vegetation indices that enabled distinction between closed and open savannah vegetation. Misclassifications observed between land-use classes were a result of small-scale intra-heterogeneity of the landscape, which caused a high number of mixed pixels and thus, negatively affected the classification accuracies. In principle, mixed pixels emanating from subpixel objects of various classes exhibit high intra-heterogeneity within a defined landscape unit [36]. Mixed pixels can affect the classification results, even as they are located along the borders between discrete and easily separable classes, though the occurrence of mixed pixels is not limited to the transition zones of landscape classes and do not underly a continuous gradient, which, in effect, leads to classification errors [36]. The use of multi-spectral Landsat imageries and the extracting of heterogeneous training data helped to overcome this challenge.

The results obtained from the geospatial analysis reveal that increasing urbanisation was prevalent during all the time slices analysed, predominantly indicating significant urban expansions from the previous time steps at the expense of vegetation cover. This agrees with previous studies $[42,54]$ that show an inverse relationship between the expansion of built-up areas and especially areas covered by vegetation. In consequence, it can be stated that urban expansion reduces the vegetated area. Beyond, the analysis shows that the urban expansion in the Wa Municipality is in a form of concentrating and expanding that is identical to the typical urban development pattern to be observed in Ghana [55]. The concentration can be observed by increasing spatial densities of built-up areas, particularly in the Wa township, the capital of the municipality. Simultaneously, there was massive expansion of built-up areas toward the peripheries of the major towns during all the time steps analysed (Figure 3). This also includes the engulfment of already existing peri-urban settlements in the Wa Municipality by urban sprawl. This is in line with the findings of Cobbinah and Amoako [56] and Kombe [57], who describe characteristic unconsolidated lateral physical urban expansion and urban sprawl with the engulfment of existing built-up areas by new settlements within the peripheral areas of most cities in developing countries.

Urban expansion in the Wa Municipality between 1990 and 2020 strongly correlates to population growth. According to Ghana statistical service [58], the population of the Wa Municipality increased from 98,675 inhabitants in the year 2000 to 107,214 inhabitants in 2010. This corresponds to an annual growth rate of about $0.77 \%$ in the decade of 2000-2010, while, simultaneously, settlement expansion totalled 3.71\%. For 2020, the projected population amounted to 132,646 [59], which puts the annual growth rate between 2010 and 2020 at $1.92 \%$, while, in parallel, the observed annual rate of settlement expansion 
averaged $4.1 \%$. This observation underlines the critical role that population pressure has on urban expansion and agrees with observations on land cover change in West Africa by Herrmann [60], who revealed that changing intensities of settlement areas were significantly influenced by population pressure. Spatial patterns of the human footprint within the area of the Wa Municipality suggest that population pressure coupled with the socioeconomic statuses of the people and policies geared toward infrastructure development affect the complexity of land cover outcomes. The infrastructure expansion in the Wa Municipality manifests in the LULC changes in the area: the Wa airport, for example, is a prominent infrastructure measure visible in the satellite imageries. It influenced the expansion of the settlement space, especially in the year 2001 and beyond. Evidence from previous research suggests that other infrastructure measures, such as roads, schools and hospitals, were part of the development phase from 1990 to 2020 as a response to the population's demand [61,62], thus controlling large parts of the dynamics in LULC changes within this period.

It was evident that areas previously covered by savannah vegetation changed to settlement areas, as proven for all the time slices selected. This also became explicit in the LULC classification that shows significant spatial settlement expansion in all the time slices. While in the Wa Municipality settlement expansion was prominent, woody biomass, on the other hand, shrank over the past decades; this was confirmed by the LULC analysis based on the satellite images that revealed a depletion of closed savannah vegetation for all the time steps analysed. Between 1990 and 2001, there was a gain in the settlement area in the Wa Municipality of $11.68 \mathrm{~km}^{2}$ corresponding to a relative increase of $61.09 \%$, while in parallel, there was a reduction of areas covered with closed savannah vegetation by $9.37 \mathrm{~km}^{2}$ corresponding to a relative decrease of $7.85 \%$. This inverse relationship can be observed for all time steps analysed, with the overall gain in settlement area between 1990 and 2020 of $52.42 \mathrm{~km}^{2}(+87.57 \%)$ and the corresponding loss in areas covered by closed savannah vegetation of $37.35 \mathrm{~km}^{2}(-40.89 \%)$. This reflects the effects of the characteristic urban agglomeration-population nexus typical of contemporary times, where landscape degradation associated with urban expansion is driven by the need for shelter for the increasing population who engages in livelihood development activities in their respective settlements $[63,64]$. The current trends of urban expansion and vegetation dynamics in the Wa Municipality is in line with Bologna and Aquino [65], who emphasise a populationurban expansion-deforestation nexus, maintaining that the essential services derived in support of human life is the main driving force behind encroachment on forest spaces. This is supported by Myers et al. [66], who stated that changes in terrestrial ecosystems are influenced by increasing pressure emanating from population growth, which in effect degrades the landscape and its associated resources.

In Ghana, north to south migration is typical for the exploration of livelihood development options. Beyond, people also move within their districts and municipalities, due to the push factors to access resources such as fertile land and water to secure their livelihood [67]. Next to LULC change as an effect of migration and population growth, there has been, in most recent times, an increase in the proliferation of unregulated small-scale gold mining within the Wa Municipality and its neighbouring Wa East district [67]. These economic opportunities are a strong pull factor for intra- and inter-district migration and affect the LULC pattern. While agriculture is the major livelihood and economic development activity in the Wa Municipality, some inhabitants are shifting to unregulated small-scale mining, which seems to be more lucrative and yields the promise of quick income, despite the environmental consequences it poses. Basommi et al. [37] observed that settlements expanded within the Wa East district, which has neighboured the Wa Municipality in gold mining activities in the area over the past years. Currently, the unregulated small-scale mining operations cause destruction of the ecosystem [37,68].

In the Wa Municipality, the cutting of trees for fuelwood and charcoal production is the major cause of woody biomass depletion $[48,50,69]$, affecting the decline in closed savannah vegetation. In addition, seasonal bushfires occurring predominantly during harmattan 
seasons (November to March) also contribute to the depletion of woody vegetation [70]. Despite the devastating effects of bushfires on livelihood, there is a lack of understanding of its causes and a clear policy direction to address it [71]. Rainfall in northern Ghana is unimodal with high spatial and temporal variability with the rainy season between May and September [72]. Due to the seasonal occurrence of rainfall, runoff regimes of the major rivers are periodical, causing a water shortage during the dry season. As surface water is an important water source for agricultural activities, the study area is significantly impacted by the competing demand for water between domestic and agricultural uses [73]. The increased availability of water, deviated from the extent of open water areas, as seen in the satellite images from 2010 and 2020, is in line with government efforts to construct dams and dugouts to ensure water availability to sustain agriculture and guarantee livelihoods [74]. Expanding vegetation in the vicinity of the wetlands suggests that in periods of increased water availability, the vegetated wetland expands.

Among the topographical characteristics, slope, aspect and TWI are key determinants to choose land for settlement $[75,76]$. Location factors, such as distance to existing settlements, distance to water sources, and distance to tertiary and primary roads also play major role in urban expansion. Additionally, the proximity to physical infrastructure and water resources is a driving factor of urban growth, as people are pulled toward areas that are endowed with a physical infrastructure and water resources for economic and livelihood activities [44,77]. However, by applying binary logistic regression to determine the drivers of urban expansion, it is evident that the topographic factors of slope, aspect and TWI did not obtain statistically significant coefficients to predict the odd logs of their probabilities of influence on urban expansion within the Wa Municipality for all the time steps analysed. This might be due to the nature of the entire landscape, which is almost homogenous and has almost equal suitability of selection for settlement. On the other hand, drivers such as distance to settlement, distance to road networks, and distance to water were statistically significant for all the time steps analysed, strongly indicating their influence on urban expansion. These physical location drivers' influence on urban expansion was reinforced by the direction of the expansion that was predominantly towards the south-western part of the Wa Municipality, where major primary, tertiary and unclassified road networks are densely formed. This finding is in line with studies conducted in national and regional contexts, all establishing a significant relation between physical location factors and urban expansion [78,79]. Pravitasari et al. [80] underlined in their study on the Jakarta-Bandung mega urban region and asserted that among the major drivers of urban expansion is the distance to road, which directly affects the extent and spatial expansion of the area. Similarly, Marondedze and Schütt [42] identified roads as a major determinant of urban expansion for the Epworth district, Harare, Zimbabwe. In the Wa Municipality, urban expansion is being driven by the government's commitment to the provision of infrastructure, such as roads, schools as part of development agenda. Considering the trend of urban expansion in the Wa Municipality, it is evident that people choose to live close to roads to have easy access to the workplace, school and market. Distance to primary, tertiary and unclassified roads were statistically significant with a negative coefficient, indicating an increased probability of an area being transformed to an urban space controlled by the proximity of the area to roads; thus, the shorter the distance of an area to a road, the higher the possibility of the area being expanded into an urban space.

Beyond, the development of the Wa Municipality and the expansion of built-up areas since the year 2000 was also affected by the establishment of the Wa Campus of the University for Development Studies (now called S.D. Dombo University of Business and Integrated Development Studies), Wa Polytechnic (now called Wa Technical University) and a nursing training college, all distributed across the municipality and acting as pull factors [81].

Distance to already existing settlements was also established as a key driver for urban expansion. For all the time steps analysed (1990-2001, 2001-2010 and 2010-2020), the binomial logistic regression shows statistically significant negative coefficients describing 
the relation between new built-up areas and distance to existing settlements. The result agrees with findings from previous studies, which also observed urban expansion to be influenced by distance to existing settlements and other locations [41,44]. The negative coefficient of distance to existing settlement observed for all the time slices in the logistic regression analysis underscores the increasing likelihood of newly developed settlements near already existing settlements, and thus settlement expansion. This observation can be attributed to the higher affinity for easy access to socioeconomic resources and better development opportunities in existing settlement, especially closer to the administrative centre of the municipality [82].

According to Li et al. [83], the presence of water bodies in an area could either hinder or promote urban expansion corresponding to the waterborne advantages as well as the opportunities that water resources present for urban development. Correspondingly, proximity to rivers is established as a key driver of urban expansion, proven to be statistically significant with new built-up areas for the time steps 1990-2001 and 2001-2010; considering the data for the entire observation period (1990-2020), also a statistically significant relation between the development of new built-up areas and their distance to rivers can be observed. The result suggests an increasing probability of urban expansion at a location, the closer the distance to open water is. This finding is consistent with findings by $[44,45,83]$ for studies conducted in Asia. During the Colonial era, the people of the Wa Municipality largely relied on hand-dug wells, streams and rivers to cover their daily water needs. In the 1950s, the Hydraulic Division of Public Works Department was mandated to plan and develop water supply systems for the provision of portable water in the Wa Municipality [84]. During the $1950 \mathrm{~s}$, the water allocation capacity was as low as $150 \mathrm{~m}^{3}$ per day and increased to about $1320 \mathrm{~m}^{3}$ daily water allocation in the 1980s as the ever-increasing population necessitated increasing water availability [84]. Currently, Ghana Water Company Limited is responsible for the operation of the water supply system in the Wa Municipality, with a daily demand of more than $12,000 \mathrm{~m}^{3}$. As developments and associated infrastructure are still in progress, in particular, the rural population still relies on open water from rivers for domestic and agricultural purposes [17].

\section{Conclusions}

Over the past decades, landscapes have been influenced significantly by climate variability and anthropogenic impacts. The proliferation of rural settlements and urban expansion has further led to landscapes' modification, as vegetation cover and environmental resources deplete. Owing to the environmental conditions and development potential of Wa Municipality of Ghana, assessment of the dynamics of land cover and drivers of settlement expansion is a great step to inform developmental policies. This study provides insight into landscape dynamics and the drivers of urban expansion in the Wa Municipality, Ghana, by employing geospatial and remote sensing tools coupled by a binomial logistic regression model. By employing supervised LULC classification using the random forest classifier, we obtained satisfactory overall accuracies. Similarly, we obtained great performance of the binomial logistic model, as the model validation yielded excellent output. The study reveals that the landscape of the Wa Municipality over the past three decades has been influenced by urban expansion, while in parallel, woody biomass has reduced as observed in the reduction of areas covered by closed savannah vegetation. We note that during the 1990-2020 observation period, settlement expansion for all the time steps analysed was consistent with the trend of regional population growth. The urban expansion is relatively compact within the capital city of the Wa Municipality as a result of the infilling of open spaces within the city complex. However, the peripheral areas of the capital city expanded predominantly toward the south-west part of the Wa Municipality. This behaviour was observed for all 10 years' time steps analysed. In parallel, for all 10 years' time steps analysed, a decrease in areas covered by savannah vegetation can be observed. Even when the urban spread predominantly captures areas with bare 
land, population pressure, and grazing activities as well as fuel wood consumption as a concomitant phenomenon of the urban spread trigger the decline in savannah vegetation.

In consonance with other studies, the LULC change dynamics observed for the Wa Municipality reflect the resultant effects of the influx of population growth and the associated demand for environmental resources for sustainable livelihood and economic development. The drivers identified to influence settlement expansion include distance to existing settlements, distance to rivers and distance road networks. The development of settlements near an already existing settlement is imperative, due to the potential economic development opportunities they present. Beyond, accessibility and connectivity seem eminent, as distance to roads was also proven to be a driver for settlement expansion. In line with the new spatial planning framework of Ghana, our findings provide relevant information for the Town and Country Planning Department for future development plans of the Wa Municipality. Beyond, our findings provide valuable knowledge to support integrated landscape management decisions and its impacts on the ecosystem and environmental resources. It is expected that future research would expand the scope of the study beyond the Wa Municipality and explore the landscape dynamics and drivers of urban expansion at the macro level. Additionally, beyond the geophysical factors, future research should explore the socioeconomic drivers of urban expansion at the municipal level and beyond. This, together with our findings, inform a holistic framework in sustainable urban planning and development.

Supplementary Materials: The following are available online at https:/ /www.mdpi.com/article/ 10.3390/land10111251/s1, Figure S1: The Raster layer of urban expansion obtained from change detection for all the time slices and served as dependant variables in the logistic regression analysis, Figure S2: Raster layers of the topographic independent variables explored for relationship with urban expansion, Figure S3: Raster layers of the location independent variables explored for their relationship with urban expansion, Table S1: Landsat satellite used for classification, their scene ID number and the time of acquisition.

Author Contributions: Conceptualisation, M.A.; methodology, M.A.; software, M.A.; validation, M.A.; formal analysis, M.A.; investigation, M.A.; resources, M.A.; data curation, M.A. and W.S.; visualisation, M.A.; writing —original draft preparation, M.A.; writing—review and editing, W.S. and B.S.; supervision, B.S.; project administration, funding acquisition, M.A. and B.S. All authors have read and agreed to the published version of the manuscript.

Funding: We thank the German Academic Exchange Service (DAAD), who provided a fellowship to conduct this study. Also, we are thankful to Freie Universität Berlin for providing financial support for the publication of this article.

Institutional Review Board Statement: Not applicable.

Informed Consent Statement: Not applicable.

Data Availability Statement: Not applicable.

Acknowledgments: We express our appreciation to colleagues from the Freie Universität for their valuable insights and expertise that greatly assisted this study. We also thank the staff of the Water Resources Commission of Ghana, especially those in the Wa Municipality, for their assistance during the field campaign. Finally, we are grateful to the National Aeronautics and Space Administration (NASA) and the United States Geological Survey (USGS), who kindly provided the Landsat imagery and the one Arc-Second Global data from the Shuttle Radar Topography Mission (SRTM) for the study.

Conflicts of Interest: The authors declare no conflict of interest. The roles in the design of the study; in the collection, analyses, or interpretation of data; in the writing of the manuscript; and the decision to publish the results are solely by the authors. 


\section{References}

1. Chen, G.; Li, X.; Liu, X.; Chen, Y.; Liang, X.; Leng, J.; Xu, X.; Liao, W.; Qiu, Y.; Wu, Q.; et al. Global Projections of Future Urban Land Expansion under Shared Socioeconomic Pathways. Nat. Commun. 2020, 11, 537. [CrossRef] [PubMed]

2. Flörke, M.; Schneider, C.; McDonald, R.I. Water Competition between Cities and Agriculture Driven by Climate Change and Urban Growth. Nat. Sustain. 2018, 1, 51-58. [CrossRef]

3. Seto, K.C.; Sánchez-Rodríguez, R.; Fragkias, M. The New Geography of Contemporary Urbanization and the Environment. Annu. Rev. Environ. Resour. 2010, 35, 167-194. [CrossRef]

4. Wang, W.; Wu, T.; Li, Y.; Xie, S.; Han, B.; Zheng, H.; Ouyang, Z. Urbanization Impacts on Natural Habitat and Ecosystem Services in the Guangdong-Hong Kong-Macao "Megacity". Sustainability 2020, 12, 6675. [CrossRef]

5. Churkina, G. The Role of Urbanization in the Global Carbon Cycle. Front. Ecol. Evol. 2016, 3, 1-9. [CrossRef]

6. Bren d'Amour, C.; Reitsma, F.; Baiocchi, G.; Barthel, S.; Güneralp, B.; Erb, K.-H.; Haberl, H.; Creutzig, F.; Seto, K.C. Future Urban Land Expansion and Implications for Global Croplands. Proc. Natl. Acad. Sci. USA 2017, 114, 8939-8944. [CrossRef] [PubMed]

7. United Nations, Department of Economic and Social Affairs, Population Division. World Urbanization Prospects, the 2014 Revision: Highlights; ST. ESA; United Nations: New York, NY, USA, 2014; ISBN 978-92-1-151517-6.

8. $\quad$ Elmqvist, T.; Fragkias, M.; Goodness, J.; Güneralp, B.; Marcotullio, P.J.; McDonald, R.I.; Parnell, S.; Schewenius, M.; Sendstad, M.; Seto, K.C.; et al. (Eds.) Urbanization, Biodiversity and Ecosystem Services: Challenges and Opportunities: A Global Assessment; Springer: Berlin/Heidelberg, Germany, 2013. [CrossRef]

9. Seto, K.C.; Fragkias, M.; Güneralp, B.; Reilly, M.K. A Meta-Analysis of Global Urban Land Expansion. PLoS ONE 2011, 6, e23777. [CrossRef]

10. McKinney, M.L. Urbanization, Biodiversity, and Conservation. BioScience 2002, 52, 883. [CrossRef]

11. Solecki, W.; Seto, K.C.; Marcotullio, P.J. It's Time for an Urbanization Science. Environ. Sci. Policy Sustain. Develop. 2013, 55, 12-17. [CrossRef]

12. Hails, R.S.; Ormerod, S.J. EDITORIAL: Ecological Science for Ecosystem Services and the Stewardship of Natural Capital. J. Appl. Ecol. 2013, 50, 807-810. [CrossRef]

13. Ferreira, L.M.R.; Esteves, L.S.; de Souza, E.P.; dos Santos, C.A.C. Impact of the Urbanisation Process in the Availability of Ecosystem Services in a Tropical Ecotone Area. Ecosystems 2019, 22, 266-282. [CrossRef]

14. Ampim, P.A.Y.; Ogbe, M.; Obeng, E.; Akley, E.K.; MacCarthy, D.S. Land Cover Changes in Ghana over the Past 24 Years. Sustainability 2021, 13, 4951. [CrossRef]

15. United Nations, Department of Economic and Social Affairs, Population Division. World Urbanization Prospects: The 2018 Revision; United Nations: New York, NY, USA, 2019; ISBN 978-92-1-148319-2.

16. Güneralp, B.; Lwasa, S.; Masundire, H.; Parnell, S.; Seto, K.C. Urbanization in Africa: Challenges and Opportunities for Conservation. Environ. Res. Lett. 2017, 13, 015002. [CrossRef]

17. Ghana Statistics Service. The 2010 Population and Housing Census:District Analytical Report, Wa Municipality; Awusabo-Asare, K., Nsowah-Nuamah, N.N.N., Anaman, A.K., Gaisie, S.K., Eds.; Ghana Statistics Service: Accra, Ghana, 2014.

18. Statistics, Research and Information Directorate (SRID). Agriculture in Ghana: Facts and Figures; Ministry of Food and Agriculture: Accra, Ghana, 2011.

19. Ham, J.R. Cooking to Be Modern but Eating to Be Healthy: The Role of Dawa-Dawa in Contemporary Ghanaian Foodways. Food Cult. Soc. 2017, 20, 237-256. [CrossRef]

20. Kent, R. "Helping" or "Appropriating"? Gender Relations in Shea Nut Production in Northern Ghana. Soc. Nat. Resour. 2018, 31, 367-381. [CrossRef]

21. Kpienbaareh, D.L. Assessing the Relationship between Climate and Patterns of Wildfires in Ghana. Int. J. Humanit. Soc. Sci. 2016, 8,1-20.

22. Kpienbaareh, D.; Oduro Appiah, J. A Geospatial Approach to Assessing Land Change in the Built-up Landscape of Wa Municipality of Ghana. Geogr. Tidsskr. Dan. J. Geogr. 2019, 119, 121-135. [CrossRef]

23. Storey, J.; Scaramuzza, P.; Schmidt, G.; Barsi, J. Landsat 7 Scan Line Corrector-off Gap-Filled Product Development. Proc. Pecora 2005, 16, 23-27.

24. Paolini, L.; Grings, F.; Sobrino, J.A.; Jiménez Muñoz, J.C.; Karszenbaum, H. Radiometric Correction Effects in Landsat Multidate/Multi-sensor Change Detection Studies. Int. J. Remote Sens. 2006, 27, 685-704. [CrossRef]

25. Song, C.; Woodcock, C.E.; Seto, K.C.; Lenney, M.P.; Macomber, S.A. Classification and Change Detection Using Landsat TM Data: When and How to Correct Atmospheric Effects? Remote Sens. Environ. 2001, 75, 230-244. [CrossRef]

26. Woodcock, C.E.; Macomber, S.A.; Pax-Lenney, M.; Cohen, W.B. Monitoring Large Areas for Forest Change Using Landsat: Generalization across Space, Time and Landsat Sensors. Remote Sens. Environ. 2001, 78, 194-203. [CrossRef]

27. Sinha, S.; Sharma, L.K.; Nathawat, M.S. Improved Land-Use/Land-Cover Classification of Semi-Arid Deciduous Forest Landscape Using Thermal Remote Sensing. Egypt. J. Remote Sens. Space Sci. 2015, 18, 217-233. [CrossRef]

28. Weng, Q.; Lu, D.; Schubring, J. Estimation of Land Surface Temperature-Vegetation Abundance Relationship for Urban Heat Island Studies. Remote Sens. Environ. 2004, 89, 467-483. [CrossRef]

29. Robinson, N.; Allred, B.; Jones, M.; Moreno, A.; Kimball, J.; Naugle, D.; Erickson, T.; Richardson, A. A Dynamic Landsat Derived Normalized Difference Vegetation Index (NDVI) Product for the Conterminous United States. Remote Sens. 2017,9 , 863. [CrossRef] 
30. Rouse, J.W.; Haar, R.; Scheel, J.; Deering, D. Monitoring Vegetation Systems in the Great Plains with ERTS. In Proceedings of the NASA, Technical Presentations Section A, Washington, DC, USA, 10-14 December 1973.

31. Singh, K.V.; Setia, R.; Sahoo, S.; Prasad, A.; Pateriya, B. Evaluation of NDWI and MNDWI for Assessment of Waterlogging by Integrating Digital Elevation Model and Groundwater Level. Geocarto Int. 2015, 30, 650-661. [CrossRef]

32. Xu, H. Modification of Normalised Difference Water Index (NDWI) to Enhance Open Water Features in Remotely Sensed Imagery. Int. J. Remote Sens. 2006, 27, 3025-3033. [CrossRef]

33. Zha, Y.; Gao, J.; Ni, S. Use of Normalized Difference Built-up Index in Automatically Mapping Urban Areas from TM Imagery. Int. J. Remote Sens. 2003, 24, 583-594. [CrossRef]

34. Xue, J.; Su, B. Significant Remote Sensing Vegetation Indices: A Review of Developments and Applications. J. Sens. 2017, 2017, 1-17. [CrossRef]

35. McFeeters, S.K. The Use of the Normalized Difference Water Index (NDWI) in the Delineation of Open Water Features. Int. J. Remote Sens. 1996, 17, 1425-1432. [CrossRef]

36. Phiri, D.; Morgenroth, J. Developments in Landsat Land Cover Classification Methods: A Review. Remote Sens. 2017,9 , 967. [CrossRef]

37. Basommi, P.L.; Guan, Q.; Cheng, D. Exploring Land Use and Land Cover Change in Themining Areas of Wa East District, Ghana UsingSatellite Imagery. Open Geosci. 2015, 7, 20150058. [CrossRef]

38. Schubert, H.; Caballero Calvo, A.; Rauchecker, M.; Rojas-Zamora, O.; Brokamp, G.; Schütt, B. Assessment of Land Cover Changes in the Hinterland of Barranquilla (Colombia) Using Landsat Imagery and Logistic Regression. Land 2018, 7, 152. [CrossRef]

39. Borrelli, P.; Armenteras, D.; Panagos, P.; Modugno, S.; Schütt, B. The Implications of Fire Management in the Andean Paramo: A Preliminary Assessment Using Satellite Remote Sensing. Remote Sens. 2015, 7, 11061-11082. [CrossRef]

40. Xu, Q.; Zheng, X.; Zhang, C. Quantitative Analysis of the Determinants Influencing Urban Expansion: A Case Study in Beijing, China. Sustainability 2018, 10, 1630. [CrossRef]

41. Dubovyk, O.; Sliuzas, R.; Flacke, J. Spatio-Temporal Modelling of Informal Settlement Development in Sancaktepe District, Istanbul, Turkey. ISPRS J. Photogramm. Remote Sens. 2011, 66, 235-246. [CrossRef]

42. Marondedze, A.K.; Schütt, B. Dynamics of Land Use and Land Cover Changes in Harare, Zimbabwe: A Case Study on the Linkage between Drivers and the Axis of Urban Expansion. Land 2019, 8, 155. [CrossRef]

43. Li, X.; Zhou, W.; Ouyang, Z. Forty Years of Urban Expansion in Beijing: What Is the Relative Importance of Physical, Socioeconomic, and Neighborhood Factors? Appl. Geogr. 2013, 38, 1-10. [CrossRef]

44. Luo, J.; Wei, Y.H.D. Modeling Spatial Variations of Urban Growth Patterns in Chinese Cities: The Case of Nanjing. Landsc. Urban Plan. 2009, 91, 51-64. [CrossRef]

45. Cheng, J.; Masser, I. Urban Growth Pattern Modeling: A Case Study of Wuhan City, PR China. Landsc. Urban Plan. 2003, 62, 199-217. [CrossRef]

46. Batisani, N.; Yarnal, B. Urban Expansion in Centre County, Pennsylvania: Spatial Dynamics and Landscape Transformations. Appl. Geogr. 2009, 29, 235-249. [CrossRef]

47. Anselm, N.; Brokamp, G.; Schütt, B. Assessment of Land Cover Change in Peri-Urban High Andean Environments South of Bogotá, Colombia. Land 2018, 7, 75. [CrossRef]

48. Sedano, F.; Silva, J.A.; Machoco, R.; Meque, C.H.; Sitoe, A.; Ribeiro, N.; Anderson, K.; Ombe, Z.A.; Baule, S.H.; Tucker, C.J. The Impact of Charcoal Production on Forest Degradation: A Case Study in Tete, Mozambique. Environ. Res. Lett. 2016, 11, 094020. [CrossRef] [PubMed]

49. Attua, E.M.; Fisher, J.B. Historical and Future Land-Cover Change in a Municipality of Ghana. Earth Interact. 2011, 15, 1-26. [CrossRef]

50. Carranza-García, M.; García-Gutiérrez, J.; Riquelme, J. A Framework for Evaluating Land Use and Land Cover Classification Using Convolutional Neural Networks. Remote Sens. 2019, 11, 274. [CrossRef]

51. Talukdar, S.; Singha, P.; Mahato, S.; Shahfahad, P.S.; Liou, Y.-A.; Rahman, A. Land-Use Land-Cover Classification by Machine Learning Classifiers for Satellite Observations-A Review. Remote Sens. 2020, 12, 1135. [CrossRef]

52. Mountrakis, G.; Im, J.; Ogole, C. Support Vector Machines in Remote Sensing: A Review. ISPRS J. Photogramm. Remote Sens. 2011, 66, 247-259. [CrossRef]

53. Ma, L.; Li, M.; Ma, X.; Cheng, L.; Du, P.; Liu, Y. A Review of Supervised Object-Based Land-Cover Image Classification. ISPRS J. Photogramm. Remote Sens. 2017, 130, 277-293. [CrossRef]

54. Hegazy, I.R.; Kaloop, M.R. Monitoring Urban Growth and Land Use Change Detection with GIS and Remote Sensing Techniques in Daqahlia Governorate Egypt. Int. J. Sustain. Built Environ. 2015, 4, 117-124. [CrossRef]

55. Kuusaana, E.D.; Kosoe, E.A.; Niminga-Beka, R.Y.; Ahmed, A. Spatial Justice and Inner-City Development in Secondary Cities of Ghana: Implications for New Urban Agenda in the Global South. Urban Forum 2021, 32, 373-391. [CrossRef]

56. Cobbinah, P.B.; Amoako, C. Urban Sprawl and the Loss of Peri-Urban Land in Kumasi, Ghana. Int. J. Soc. Hum. Sci. 2012, 6, 390-397.

57. Kombe, W.J. Land Use Dynamics in Peri-Urban Areas and Their Implications on the Urban Growth and Form: The Case of Dar Es Salaam, Tanzania. Habitat Int. 2005, 29, 113-135. [CrossRef]

58. Ghana Statistical Service. Policy Implications of Population Trends, Population Data Analysis Reports; Twum-Baah, K.A., Kumekpor, T.K.B., Aryee, A.F., Gaisie, S.K., Eds.; Ghana Statistical Service: Accra, Ghana, 2005; Volume 2, pp. 1-495. 
59. Ghana Statistical Service. The 2010 Population and Housing Census: Summary Report of Final Results; Sakoa Press Limited: Accra, Ghana, 2012.

60. Herrmann, S.M.; Brandt, M.; Rasmussen, K.; Fensholt, R. Accelerating Land Cover Change in West Africa over Four Decades as Population Pressure Increased. Commun Earth Environ. 2020, 1, 53. [CrossRef]

61. Ziem Bonye, S.; Yenglier Yiridomoh, G.; Derbile, E.K. Urban Expansion and Agricultural Land Use Change in Ghana: Implications for Peri-Urban Farmer Household Food Security in Wa Municipality. Int. J. Urban Sustain. Dev. 2021, 13, 383-399. [CrossRef]

62. Osumanu, I.K.; Akongbangre, J.N.; Tuu, G.N.-Y.; Owusu-Sekyere, E. From Patches of Villages to a Municipality: Time, Space, and Expansion of Wa, Ghana. Urban Forum 2019, 30, 57-74. [CrossRef]

63. Acheampong, R.A.; Anokye, P.A. Understanding Households' Residential Location Choice in Kumasi's Peri-Urban Settlements and the Implications for Sustainable Urban Growth. Res. Hum. Soc. Sci. 2013, 3, 60-70.

64. Appiah, D.O.; Bugri, J.T.; Forkuor, E.K.; Boateng, P.K. Determinants of Peri-Urbanization and Land Use Change Patterns in Peri-Urban Ghana. JSD 2014, 7, 95. [CrossRef]

65. Bologna, M.; Aquino, G. Deforestation and World Population Sustainability: A Quantitative Analysis. Sci Rep 2020, 10, 7631. [CrossRef] [PubMed]

66. Myers, S.S.; Gaffikin, L.; Golden, C.D.; Ostfeld, R.S.; Redford, H.K.; Ricketts, H.T.; Turner, W.R.; Osofsky, S.A. Human Health Impacts of Ecosystem Alteration. Proc. Natl. Acad. Sci. USA 2013, 110, 18753-18760. [CrossRef]

67. Antabe, R.; Atuoye, K.N.; Kuuire, V.Z.; Sano, Y.; Arku, G.; Luginaah, I. Community Health Impacts of Surface Mining in the Upper West Region of Ghana: The Roles of Mining Odors and Dust. Hum. Ecol. Risk Assess. Int. J. 2017, 23, 798-813. [CrossRef]

68. Mucova, S.A.R.; Filho, W.L.; Azeiteiro, U.M.; Pereira, M.J. Assessment of Land Use and Land Cover Changes from 1979 to 2017 and Biodiversity \& Land Management Approach in Quirimbas National Park, Northern Mozambique, Africa. Glob. Ecol. Conserv. 2018, 16, e00447. [CrossRef]

69. Chiteculo, V.; Lojka, B.; Surový, P.; Verner, V.; Panagiotidis, D.; Woitsch, J. Value Chain of Charcoal Production and Implications for Forest Degradation: Case Study of Bié Province, Angola. Environments 2018, 5, 113. [CrossRef]

70. Kusakari, Y.; Asubonteng, K.O.; Jasaw, G.S.; Dayour, F.; Dzivenu, T.; Lolig, V.; Donkoh, S.A.; Obeng, F.K.; Gandaa, B.; Kranjac-Berisavljevic, G.; et al. Farmer-Perceived Effects of Climate Change on Livelihoods in Wa West District, Upper West Region of Ghana. J. Disaster Res. 2014, 9, 516-528. [CrossRef]

71. Yahaya, A.K.; Amoah, S.T. Bushfires in the Nandom District of the Upper West Region of Ghana: Perpetual Threat to Food Crop Production. J. Environ. Earth Sci. 2013, 3, 10-14.

72. Yengoh, G.T.; Armah, F.A.; Onumah, E.E.; Odoi, J.O. Trends in Agriculturally-Relevant Rainfall Characteristics for Small-Scale Agriculture in Northern Ghana. J. Agric. Sci. 2010, 2, 3. [CrossRef]

73. Benebere, P.; Asante, F.; Odame Appiah, D. Hindrances to Adaptation to Water Insecurity under Climate Variability in Peri-Urban Ghana. Cogent Soc. Sci. 2017, 3, 1394786. [CrossRef]

74. Diko, S.K.; Okyere, S.A.; Opoku Mensah, S.; Ahmed, A.; Yamoah, O.; Kita, M. Are Local Development Plans Mainstreaming Climate-Smart Agriculture? A Mixed-Content Analysis of Medium-Term Development Plans in Semi-Arid Ghana. Socio. Ecol. Pract. Res. 2021, 3, 185-206. [CrossRef]

75. Zhang, Z.; Xiao, R.; Shortridge, A.; Wu, J. Spatial Point Pattern Analysis of Human Settlements and Geographical Associations in Eastern Coastal China-A Case Study. Int. J. Environ. Res. Public Health 2014, 11, 2818-2833. [CrossRef] [PubMed]

76. Ye, Y.; LeGates, R.; Qin, B. Coordinated Urban-Rural Development Planning in China: The Chengdu Model. J. Am. Plan. Assoc. 2013, 79, 125-137. [CrossRef]

77. Poelmans, L.; Van Rompaey, A. Detecting and Modelling Spatial Patterns of Urban Sprawl in Highly Fragmented Areas: A Case Study in the Flanders-Brussels Region. Landsc. Urban Plan. 2009, 93, 10-19. [CrossRef]

78. Das Chatterjee, N.; Chatterjee, S.; Khan, A. Spatial Modeling of Urban Sprawl around Greater Bhubaneswar City, India. Model. Earth Syst. Environ. 2016, 2, 14. [CrossRef]

79. Poku-Boansi, M.; Adarkwa, K.K. Determinants of Residential Location in the Adenta Municipality, Ghana. GeoJournal 2016, 81, 779-791. [CrossRef]

80. Pravitasari, A.E.; Rustiadi, E.; Mulya, S.P.; Setiawan, Y.; Fuadina, L.N.; Murtadho, A. Identifying the Driving Forces of Urban Expansion and Its Environmental Impact in Jakarta-Bandung Mega Urban Region. IOP Conf. Ser. Earth Environ. Sci. 2018, 149, 012044. [CrossRef]

81. Korah, P.I.; Nunbogu, A.M.; Akanbang, B.A.A. Spatio-Temporal Dynamics and Livelihoods Transformation in Wa, Ghana. Land Use Policy 2018, 77, 174-185. [CrossRef]

82. Boamah, N.A. Urban Land Market in Ghana: A Study of the Wa Municipality. Urban Forum 2013, 24, 105-118. [CrossRef]

83. Li, G.; Sun, S.; Fang, C. The Varying Driving Forces of Urban Expansion in China: Insights from a Spatial-Temporal Analysis. Landsc. Urban Plan. 2018, 174, 63-77. [CrossRef]

84. Amoah, S.T. Evolution of Water Systems and Its Challenges in the Wa Municipal of Ghana. J. Environ. Earth Sci. 2013, 3, 15-24. 